\title{
İnsan ve Anlam Temelinde Adil, Kapsayıcı ve Bütüncül Eğitim Politikalarının Kavramsal İnşası
}

\author{
MUSTAFA YAVUZ \\ mustafaya2002@gmail.com \\ ORCID ID: 0000-0001-5697-5120
}

\begin{abstract}
Öz: Eğitim sistemleri canlı organizmalardır. Nefes alıp verirler. Bazen de krize girebilirler. Ancak sistemi oluşturan insan, anlam ve imkânlar etkili bir şekilde çalı̧̧abilirlerse krizler yeni firsatlara dönüş̧ebilir. Eğitim sistemleri öncelikle devleti oluşturan bireylerin zihinlerinde inşa edilmelidir. Bir devlet veya toplum düzeyinde yapılan değerlendirmeler çoğu zaman eğitim sistemleri dikkate alınmadan yapılır. Bu nedenle değerlendirmeler çoğu zaman eksik, yanlış veya bütünlükten yoksundur. Eğitim bilimciler genel anlamda eğitim sistemine ve onun bir alt kümesi olan okula odaklandıkları için sıklıkla ülke veya toplum düzeyinde değerlendirmelere uzak kalabilirler. Hâlbuki eğitim sistemleri ve okullar nefeslerini içinde bulundukları toplumdan alırlar ve topluma verirler. Eğitim sistemleri bir toplumu, devleti sürekli yeniden ürettiği için onu anlamadan bir toplumu veya devleti anlamak mümkün değildir. Bu amaçla makale insan, okul, eğitim sistemleri, toplum ve devlet ilişkisini anlamaya odaklanmıştır. Makale alan yazın taraması yöntemiyle hazırlanmıştır. Makale, eğitim sistemi üzerinde nihai bir kanaat oluşturmay değil, öncelikle yeniden düşünmemizi amaçlamaktadır.
\end{abstract}

Anahtar kelimeler: Eğitim, Amaç, İnsan, Toplum, Devlet

\section{Giriş̧}

Toplumda en hararetli tartışılan konulardan biri içinden eğitim ve okul geçenlerdir. Bu tartışmaların ilginç tarafı farklı görüşlerin neredeyse aynı kelimeleri kullanarak anlaşamamalarıdır. Bu tartışmaların içinden ahlak, değer, başarı, özgüven, yeterlik gibi kelimeler bol miktarda geçer. Aynı notaları ve enstrümanları kullanmak aynı müziği yapmanızı sağlamaz. Aynı fırça ve boyalara sahip olmanız da aynı resmi yapabileceğiniz, yapacağınız anlamına gelmez. Eğitim tartışmaları da böyledir. Aynı kavramları kullanarak tartışmak aynı şeyleri söylediğiniz anlamına gelmez. Gerçekte bu tartışmalarda farklı görüşler aynı kelime ve kavramlarla kendi zihinlerindeki resmi yaparlar. Bazı tartışmacıların amacı da eğitimle ilgili düşünce üretmek değil, eğitimi araçsallaştırarak kendi tribünlerini coşturmak olabilir.

* Prof. Dr., Necmettin Erbakan Üniversitesi, Ahmet Keleşoğlu Eğitim Fakültesi. 
Okul bir arsa üzerine değil, değerler üzerine inşa edilir. Ancak toplumun farklı kesimlerinin "değer" kavramına yükledikleri anlam farklıdır. Bu nedenle okula yönelik neredeyse hiç bitmeyen, muhtemelen de bitmeyecek olan tartışmalar tam olarak bu noktada başlar. Örneğin, İngiltere eğitim sistemi "İngiliz değerlerinin" üzerine kuruludur. İngilizler; demokrasi, yasalara uyma, bireysel özgürlük, farklı düşünce ve inançlara tolerans ve saygıyı İngiliz değerleri olarak kabul ederler. Okulları değerlendirme sürecinde öğrencilerin İngiliz değerlerini ne kadar içselleştirdikleri önemli konu başlıklarından biridir. Amerikan eğitim sistemi, büyük oranda pragmatist felsefenin üzerine oturur. Bu nedenle 1979 ve 1980 yıllarında kabul ettikleri yasal metinlerde eğitimin öncelikli misyonunu, eşit imkânlar sağlayıp eğitimde mükemmeliyeti destekleyerek küresel rekabette hazırlanma ve öğrenci başarısını artırma olarak belirlemişlerdir. Türk eğitim sisteminin genel amaçları ise cumhuriyetin değerlerine bağlı, başlangıç noktası bireyin ilgi ve yetenekleri olan, ekonominin güncel gerçekliğinin gerektirdiği bilgi ve becerilere sahip bireyler ve vatandaşlar yetiştirmektir.

Devleti oluşturan birey ve grupların eğitim sisteminin amaçları üzerinde büyük oranda uzlaşmaya varmış olmaları, sistemin şeklinin sağlam bir zemin üzerinde oluşmasını kolaylaştırır. Eğitimde reform ihtiyacı oluştuğu durumlarda bu sağlam zemin üzerinde hareket edilebilir. Çünkü eğitimde form olmadan reform olmaz. Aksi durumda amaçlar üzerindeki zihinsel bulanıklık, sistemin sürekli, amaçsız ve plansız olarak oradan oraya sürüklenmesine neden olacaktır. Örneğin, karmaşık bir yapısı olan Pakistan eğitim sistemi, genel anlamda temel ortak değerler oluşturamadan, Urduca, İngilizce eğitim veren okulların yanı sıra farklı grupların dinî yorumlarının öğretildiği medreselerden oluşmaktadır. Pakistan eğitim sistemi, farklılığın uyumuna katkı sağlayacak olan temel değerlerden yoksun görünüyor. $\mathrm{Bu}$ durum, sistemin, farklı okul mezunlarını Pakistan vatandaşı yapmakta yeterince başarı sağlayamamasına yol açıyor. Sonuç olarak, çözüm olması gereken eğitim, bazı ülkelerde bir sorun olarak karşımıza çıkabiliyor.

İlk çağlarda dünyadaki göç hareketleri, önceleri av hayvanlarının sayısı çok olan coğrafyalara doğru iken bu durum zamanla verimli arazilere sahip coğrafyalara doğru genişlemiştir. Bugün göç hareketleri, demokrasi ve hukukun görece daha güçlü olduğu ülkelere doğrudur. Demokrasi ve hukukun güçlenmesi de ancak hem formel hem de enformel eğitim boyutunda toplumsal asgari müşterekleri sağlamakla mümkündür. Asgari müşterekler üzerinde anlaşabilen toplumlar, eğitim sistemlerinin zeminini oluşturan değerler üzerinde daha az tartışarak, maddi ve manevi kaynaklarını eğitimde günün getirdikleri ve geleceğin öngörülerine yönelik çözümlere harcayabiliyorlar. Özetle, genelde eğitim, özelde okul üzerine yapılan tartışmalar toplumsal beklentilerin okula yansımalarıdır. Bu nedenle bir toplum, eğitimi öncelikle kendisini oluşturan bireylerin zihinlerinde kavramsal olarak inşa edebilmelidir.

Bir ülkenin eğitim yöneticileri ve öğretmenlerinin bugünkü anlamda eğitim, öğrenci, okul, öğretmen, öğrenme gibi temel kavramlara yükledikleri anlamlar, eğitimle ilgili mevzuatımızdan daha değerlidir. Örneğin "Okumak istemeyen bir öğrenci okumamalı." gibi klişe bir cümle kullandığımız zaman bu cümlenin aslında ne anlama geldiği üzerinde daha kapsamlı düşünmemiz gerekir. Bir öğrencinin 
söylediği “Okumak istemiyorum.” cümlesi onun için hangi koşullarda söylenmiştir? "Bu cümleleri söyleyen öğrencilerin geldikleri ailelerin sosyoekonomik düzeyleri arasında bir benzerlik var mıdır?", "Bir öğrenci 14, 15 ve 16 yaşında böyle bir cümle kullanmışsa rasyonel olarak düşünüp doğru karar vermiş olabilir mi?”, "Okulu terk eden öğrenciler çocuk yaşta verdikleri bu kararlarla ilgili ilerleyen yaşlarında ne düşünüyor olabilirler?”, "Bu konuda araştırma sonuçları ne diyor?” sorularını kendimize sormak durumundayız. Ya da "Öğrencileri erkenden mesleki eğitime yönlendirmek gerekir.” cümlesini kullandığımızda bunun ne anlama geldiği üzerinde kendimize zor sorular sorarak düşünmemiz gerekir. "Bugünkü anlamda meslek nedir?", "Bugünün mesleklerini yapabilmek için hangi becerilere ihtiyaç var?" örneklerindeki gibi çok sayıda sorular sorarak bu sorularımıza veriye ve alan yazına dayalı cevap bulmamız gerekir. Aksi durumda sınıfımızda "Okumak istemiyorum.” diyen bir öğrenciyi "Aslında okumaması gerekir.” düşüncesine kapılarak çoğu zaman farkında olmadan ihmal edebiliriz. Bugünün dünyasını, bugünün mesleğini ve onun gerektirdiği becerileri anlamadan kararlar verirsek ileride telafisi olmayan hatalar yapabiliriz. Bu nedenlerle hem her bir yönetici ve öğretmen düzeyinde hem de genel anlamda eğitim politikalarını belirleyenler düzeyinde kararları satıhta gördüklerimiz üzerinden değil, anlam arayarak, veriye ve alan yazına dayalı olarak vermek zorundayı.

\section{Dünyada Tek Tipleşen Eğitim Sistemleri}

Genel anlamda Amerikan merkezli alan yazına ve gelişmelere paralel olarak birçok ülkede, henüz düşünce aşamasında olsa da ülkemizde "hesap veren okul ve öğretmen" beklentisi oluşmaya başlamıştır. Hesap veren okul ve öğretmen beklentisini tetikleyen durumlardan biri de 1995 yılında başlayan Matematik ve Fen Eğilimleri Araştırması (TIMMS) ve 2000 yılında başlayan Uluslararası Öğrenci Değerlendirme Programı (PISA) gibi küresel ölçekli değerlendirmelerdir. Küresel ölçekli bu değerlendirmelerden önce ülkeler birbirlerinin eğitim sistemlerinden ancak karş1laştırmalı eğitim alanı ölçeğinde ilgiliydiler. Bu süreç, eğitim sistemlerini yavaş yavaş birbirlerine benzeten dinamiklerden biridir. Küresel düzeyde ortaya konulan değerlendirme ölçütleri ülkelerin eğitim sistemlerini neye göre karşılaştırıyorsa eğitim sistemleri o alana odaklanmaya başladılar. Eğitimde amacın ne olması gerektiğini, neyin önemli olduğunu bu küresel sınav merkezleri ve onların öncelikleri belirlemeye başladı. Bugün içinden geçtiğimiz süreçte biz istesek de istemesek de buna karşı kararlı bir duruş göstermedikçe, yeni alternatifler ortaya çıkarmadıkça, farklı ülkelerdeki okullar, eğitim anlamında aynı renklere boyanıyor, bir nevi tek tip elbise giyiyorlar.

Eğitim sistemlerini tek tipleştiren etkenlerden biri de küresel ölçekte örgütlenmiş olan farklı disiplinlere ait topluluklardır. Matematik, tarih, dil vb. gibi farklı disiplinlere ait küresel örgütler düzenledikleri kongreler ve öğretim program önerileri gibi faaliyetlerle ülkeler farklı olsa da öğretim programlarını neredeyse aynılaştırmaktadırlar.

Ekonomik İşbirliği ve Kalkınma Örgütü (OECD), Dünya Bankası gibi ekonomi örgütleri; Avrupa Komisyonu bünyesinde örgütlü, Avrupa Eğitim Bilgi ağı gibi si- 
yasal örgütlenmeler hazırladıkları raporlar ve araştırmalarla bir taraftan ulusal eğitim sistemlerine katkı verirken diğer taraftan aynılaşmalarına da yol açmaktadır. Örneğin OECD ve Dünya Bankasının eğitim alanında ürettiği çalışmalar, ulusal eğitim bakanlıkları tarafından yapılan çalışmalardan daha büyük etki yaratmaktadır. Ayrıca bu örgütlerin ekonomi temelli olmaları nedeniyle ulusal öğretim programlarında gittikçe ekonominin öncelikleri artmaktadır. Süreç böyle devam ederse eğitim kurumlarını ekonomi bakanlıklarına bağlama önerilerinin gelmesi uzak bir ihtimal gibi görünmemektedir. Örneğin, Dünya Ekonomi Forumunun ${ }^{1}$ ortaya koyduğu "21. Yüzyıl Becerileri”, tamamen iş dünyasının bireyden beklentilerinden oluşmaktadır. Bu örnekteki gibi iş dünyasının beklediği beceri setleri, eğitim alan yazınında son dönemlerde çıkan makalelerin başköşelerinde yer bulmaktadır. Eğitim alan yazına hâkimiyetini gün geçtikçe artıran, "homo economicus" ortaya çıkarmayı hedefleyen, eğitim dışı örgütlerin raporları ulusal eğitim programlarının amaçları ve uygulamaları üzerinde büyük etki oluşturmaktadırlar.

Okul dışı toplumun sınırlı insan anlayışı, amaç kaymasına neden olarak okulu, insanı bir bütün olarak geliştirme işlevinden uzaklaştırmaktadır. Bu alanda çözüm ancak eğitim alanında daha etkili araştırma ve raporlar yayımlamakla gerçekleşebilir. Sonuçta kaçınılmaz olarak bu alanda bilgi üreten ülke ve kurumlar sürecin öznesi durumda olurken diğerleri sürecin nesnesi durumunda kalmaya devam edeceklerdir.

\section{Karmaşıklaşan Beklentiler ve Okulun Kaosu: Okulizm}

Okulizm, son dönemlerde bütün dünyada gittikçe artan, bireyin bütün eğitimini okuldan bekleme hastalığıdır. Büyüyen kentler, gittikçe azalan kırsal nüfus, sosyal bağların gittikçe zayıflamasına yol açıyor. Değişen sosyal yapı, çocukların büyükanne, büyükbabalar ve aile yakınlarıyla daha az iletişime geçmesine olanak veriyor. Geçmişte insanlar kendi aile işlerinde gün içerisinde çocuklarından kopmadan çalışırken bugün için ücretli işlerde çalışanların sayısı artmıştır. Çalışma biçimindeki bu değişiklik çocuklarla anne babaların gün içerindeki iletişimini zayıflatmıştır. Özellikle büyük kentlerde mahalle kültürünün neredeyse yok olması, çocukların bu alanlarda aldıkları enformel eğitimi de büyük oranda zayıflatmıştır.

Yaşanan toplumsal değişimler, çocukların aldıkları enformel eğitimin şeklini büyük oranda değiştirmiştir. Bugün için çocuklar, bu eğitimlerini çoğu zaman kontrolsüz olarak internetten almaktadırlar. Ancak internet yukarıda sayılan eğitimlerin alınabileceği alternatif bir seçenek değildir.

Artan merkezi sınav baskısı, aileler ve çocuklar için neredeyse yalnızca sınava yönelik bilgiyi önemli hâle getirmiştir. Ancak sınavlar, ailede ve toplumda alınan eğitimleri sorgulamamaktadır. Bu süreçte okullar da karnenin sağ tarafı diyebileceğimiz öğrenci davranışlarına değil, karnenin sol tarafında yer alan derslerdeki başarıya odaklanmışlardır. Eğitim; gittikçe öğrenmeye, öğrenme de gittikçe sınavda so-

\footnotetext{
${ }^{1}$ OECD, "The Future of Education and Skills Education 2030", (Position Paper), 2018, http://www.oecd. org/education/2030-project/about/documents/E2030 Position Paper (05.04.2018).pdf.
} 
rulanları öğrenmeye doğru daralmıştır. Süreç öğretmenlerin de rolünü benzer şekilde daraltmıştır. Öğretmenin başarısı, artık büyük oranda sınav sonuçlarına ne kadar etki ettiğine bağlı olarak değerlendirilmektedir.

Okulda ve çevresinde yaşanan bu değişimlere karşılık iş dünyasının okuldan beklentileri gittikçe daha karmaşık hâle geldi. Örneğin, Dünya Ekonomi Forumunun, "Geleceğin Meslekleri Raporu"na göre ${ }^{2}$ bugünün iş dünyası; karmaşık problemleri çözebilen, eleştirel düşünebilen, yaratıcı, insanları yönetebilen, birlikte çalışabilen, duygusal zekâsı yüksek, değerlendiren ve karar verebilen, müzakere ve anlaşma becerisine sahip, bilişsel esnekliği olan çalışanlar istemektedir. Benzer şekilde OECD raporu $^{3}$, yukarıda sayılanlara ilave olarak empati, sorumluluk, iş birliği gibi sosyal ve duygusal becerilerin de önemli olduğunu göstermektedir. Bununla birlikte gün içerisinde okul öncesinden yükseköğretime, bir çocuğun okul yaşantısını gözlemleyelim. Gözlem sonuçlarımız bize ne söylüyor, iş dünyasının beklentileri ile okulun bireye verdikleri birbirleriyle konuşuyorlar mı? Bu soruya çok kolay bir şekilde "evet" demek ne yazık ki pek mümkün değil.

İnsan için 300.000 yıl önce keskiler, baltalar üretebilmek günün koşullarında öncelikle bilişsel beceriye bağlı yaratıcı, yenilikçi ve teknolojik bir devrimdi. Bir arkeoloji müzesi ve teknoloji müzesi gezildiğinde görülecektir ki üretim sürecinde, ilk çağlardan bugüne insan gittikçe kaslarından daha çok bilişsel becerilerini kullanmaya başlamıştır. OECD tarafından hazırlanan "2030 İçin Beceriler" isimli raporda $^{4}$ da elle yapılan işler azalırken bilişsel becerilerle yapılan işlerin arttığını göstermektedir. Gündelik bilgilerimiz de mesleklerin ve mesleklerin gerektirdiği becerilerin değiştiğini gösteriyor. Yaşanan süreçler, mesleklerin yalnızca psikomotor becerilerle yapılamayacağını göstermektedir. İster ayakkabı ister mobilya üretin, bugünün koşullarında AR-GE yapmadan; tasarım, mühendislik (örneğin, ayakkabı üretimi için anatomi, mobilya üretimi için ergonomi) bilmeden bu mesleklerin yapılabilmesi neredeyse imkânsız hâle gelmiştir. Bu dinamik gelişmeler, okuldaki özellikle mesleki eğitim üzerinde baskı yaratmaktadır. Meslekler değiştiği için mesleki eğitimin de değişmesi gerekir. Yavuz'a göre ${ }^{5}$ insanları, çiftçiler, mühendisler, öğretmenler, doktorlar, mobilyacılar vb. şeklinde mesleklerine göre sinıflandırmak doğru değil. Bugün için insanlar ikiye ayrılır: Yaratıcı ve yenilikçi olanlar ile olmayanlar. Gerçekte, yaratıcı ve yenilikçi bütün insanlar aynı mesleğe sahiptirler. Onların esas meslekleri, yaratıcı ve yenilikçi olmaktır. Esas meslekleri yaratıcılık ve yenilikçilik olan insanların meslekleri de kaybolmaz. Onlar, bu özellikleriyle mesleklerini bugünün ve gelecek zamanın ruhuna uygun olarak dönüştürebilirler. Çünkü kendilerini her daim canlı tutarlar ve bu nedenle mesleklerinin ölmesi de mümkün değildir.

Yukarıda sayılan nedenlerle mesleki eğitim ve akademik eğitimin, suları birbirine

\footnotetext{
${ }^{2}$ Michael E. Hansen, "Higher Education Needs Dusting off for the 21st Century", World Economic Forum (WEF) İnternet Sitesi, 27 Mart, 2018, https://www.weforum.org/agenda/2018/03/make-higher-educationskills-relevant-for-students/.

${ }^{3}$ OECD, “PISA 2018 Results”, 2019, https://www.oecd.org/pisa/publications/pisa-2018-results.htm.

${ }^{4}$ OECD, "OECD Future of Education and Skills 2030 Concept Note", 2019, https://www.oecd.org/educa tion/2030-project/teaching-and-learning/learning/skills/Skills_for_2030_concept_note.pdf.

${ }^{5}$ Mustafa Yavuz, Başımıza İcat Çıkaran Çocuklar ve Gençler, Ankara: Pegem Akademi Yayınları, 2020, s.ix-x.
} 
hiç karışmayan ırmaklar gibi değil, iç içe geçmiş bir yapıda olmaları bir zorunluluktur. Mesleki eğitime akademik eğitim, akademik eğitime mesleki eğitim geni aşılamadan okulların bugünün ve geleceğin okulları olabilmesi mümkün değildir. Sanayi Devrimi'nin bir uzantısı olan ve bugünün gerçekliği ile uyumlu olmayan mesleki eğitim-akademik eğitim ayrımı sona ermek zorundadır.

Bugünün ve geleceğin mesleklerinin gerektirdiği becerilerin gittikçe karmaşık hâle gelmesi ve teknolojideki hızlı değişimler, özellikle mesleki eğitimde ekonomik olarak sürdürülebilirlik sorununu ortaya çıkarmaktadır. Bugün okula kazandırdığınız en son teknolojinin ürünü olan bir araç neredeyse alındığı an teknolojinin gerisinde kalmaktadır. Ülkelerin bu pahalı eğitimi sürdürebilmeleri kolay değildir. $\mathrm{Bu}$ nedenle mesleki eğitim, ilgili sektörlerle birlikte planlanıp yürütülmek durumundadir.

\section{Eski Elbiseye Yeni Yama: Kapsayıcı Eğitim}

Millı̂ Eğitim Bakanlığı tarafından yayımlanan istatistiklere göre ${ }^{6}$ 2019-2020 eğitim öğretim yılı net okullaşma oranları " 3 yaş $\% 12,40$, 4 yaş $\% 38,06,5$ yaş $\% 75,17,3-5$ yaş, $\% 44,02,4-5$ yaş, \%56,24, 6-9 yaş, \%98,28, 10-13 yaş \%98,64" düzeyindedir. Dünyada bugün bile her beş çocuktan biri okulda olmasa da özel eğitimden okul öncesine, akademik ve mesleki eğitime kadar önceki dönemlere göre eğitimin kapsayıcılığı artıyor diyebiliriz. Bu durum, dünyada eğitim adına en iyi gelişmelerden biri olarak sayılabilir.

Eğitimde kapsayıcılık arttıkça daha önce eğitim imkânlarından yararlanamayan öğrenciler de okullu oldular. Ancak okulların, bu yeni öğrencilerinin farklı dezavantajlara sahip olmaları nedeniyle daha çok desteğe ihtiyaçları var. Bu nedenle bugünün okullarının yeni duruma uygun olarak yeteneklerinin zenginleştirilmesi gerekir. Ancak eğitimde kapsayıcılıkla ilgili oranlar iyileşirken okulların insan ve madde kaynaklarının benzer düzeyde iyileştiğini söylemek imkânsızdır. Okullar, dün hangi çalışanlara sahiplerse bugün de aynı çalışanlara sahipler. Örneğin okullar dezavantajlı kapsamında değerlendirebileceğimiz alt sosyoekonomik düzeyden ailelerden gelen öğrenciler; engelli öğrenciler; psiko-sosyal gelişimleri ile ilgili sorun yaşayan, uyum problemi olan, akran zorbalığı gibi istenmeyen davranışlarda bulunan veya motivasyonu düşük olan öğrencilere yönelik çalışmalarda bulunacak uzmanlara sahip değiller.

Eğitimin daha az kapsayıcı olduğu, çağ nüfusunun daha az okullaşabildiği dönemlerde, okullarda hangi meslek grupları varsa bugün de aynı meslek grupları var. Dün okullarda çalışanların neredeyse tamamı öğretmendi, bugün de durum aynıdır. Üstelik öğretmenler, yukarıda sayılan dezavantajlı öğrencilere yönelik uzmanlıklarını geliştirebilmeleri için dünden farklı neredeyse hiçbir yeni eğitim almıyorlar. Yönetici ve öğretmenler, bu yeni durumla baş başa bırakılıyorlar. Bu durum bir taraftan dezavantajlı öğrencilerin etkili bir eğitim alabilmelerine engel olurken diğer taraftan öğretmenlerin motivasyonlarını düşürmekte, tükenmişlik düzeylerini artırmaktadır.

${ }^{6}$ Millî Eğitim Bakanlı̆̆ı, “Millî Eğitim İstatistikleri: Örgün Eğitim (2019/20)”, https://sgb.meb.gov.tr/ meb_iys_dosyalar/2020_09/04144812_meb_istatistikleri_orgun_egitim_2019_2020.pdf. 
Okullar eski alışkanlıkları ve yetenekleri ile yol almaya devam etmek zorunda kalıyorlar. Hâlbuki okulların sosyolojisi değişmiştir. Eğitim politikalarını belirleyenlerin okullara hem mercekle hem de mikroskopla bakmaları hayati önemdedir. Okulu dünün okulu gibi görerek politikaları ona göre belirlemek, dünün güneşiyle bugünün elbisesini kurutma çabasından başka bir anlama gelmez. Eski okul anlayışının üzerine yeni yamalar yaparak yol almak mümkün değildir. Okul felsefesi dâhil, bütün bileşenleriyle öncelikle çözümleyerek işe başlamak gerekir. Eğitim politikalarını, okulu çözümlemeden "çözmeye" kalkmak yeni sorunlar ortaya çıkarmaktan başka bir işe yaramayacaktır.

\section{Aile Eğitimin Neresinde?}

Birleşmiş Milletler tarafından "İnsani Gelişmişlik Raporu”na göre ${ }^{7}, 25$ yaş ve üzeri nüfusun eğitim yılı ortalaması; "Türkiye 7,7 yıl”, "İran 10 yıl”, Azerbaycan ve Yunanistan 10,5 yll", "Singapur 11,5 yıl", "Finlandiya 12,4 yıl", "Norveç 12,6" yıldır. 25 yaş ve üzeri, nüfusun eğitim sistemleri bakımından önemlidir. Çünkü bu yaş grubunun bir bölümünün çocukları ögrencidir. PISA raporlarından ve başka araştırma sonuçlarından da biliyoruz ki anne-baba eğitim düzeyi ile öğrenci başarısı arasında yüksek düzeyde bir ilişki vardır. Ayrıca evde sahip olunan bilgisayar, internet, kitap gibi öğrenme kaynaklarıyla öğrenci başarısı arasında pozitif yönlü bir ilişki vardır. ${ }^{8}$

Yukarıdaki veriler politika yapıcılar, yöneticiler, öğretmenler ve çocuklarla iletişimde bulunan herkese çok önemli roller yüklüyor. Veriye dayalı olarak eğitim politikaları üreteceksek eğitimle ilgili göstergelere gözümüzü kapatamayı. Yukarıdaki rakamlar bize Türk eğitim sisteminin en zayıf yönünün anne ve baba eğitimleri olduğunu göstermektedir. Bu nedenle okulu çevresiyle birlikte düşünmeden politika üretemeyiz. Okulun sadece programını, tahtasını, kitabını, sırasını değiştirmek, hacmini genişletmek yetmez. Okullarımıza mutlaka anne-baba eğitimlerini gerçekleştirebilecek yeni roller yüklememiz gerekir. Bunun için de okullarımızı mutlaka insan kaynağı bakımından zenginleştirmemiz gerekir.

\section{Eğitim Fakülteleri: Sorunun Bir Parçası mı, Çözümüin Bir Parçası mı?}

Özellikle küresel sınav sonuçları açılandığı zaman akademisyenler olarak sanki eğitim sisteminin bir parçası değilmişiz gibi değerlendirebiliyoruz. Hâlbuki Türk eğitim sisteminin bir parçası da akademidir. Her ne kadar 2020 yılına kadar eğitim fakülteleri, derslerini ve içeriklerini belirlemekte özerk olmasa da iğneyi önce akademiye batırmazsak yönetici ve öğretmenlerimize haksızlık yapmış oluruz. Eğitim fakülteleri öğretmenlerin hizmet öncesi eğitim nitelikleriyle ilgili olarak öncelikle öz değerlendirmelerini yapabilmeli ve bunu kamuoyuyla paylaşabilmelidir. Elbette bu değerlendirmeden sonra iyileştirme ve geliştirme çalışmalarını saydam ve hesap verebilir şekilde yürütmelidir. Bununla birlikte yaklaşık bir milyona ulaşan görev-

\footnotetext{
7 UNDP, “2019 Human Development Index Ranking”, 2019, http://hdr.undp.org/en/content/2019-humandevelopment-index-ranking.

${ }^{8}$ Millî Eğitim Bakanlığı, "PISA 2108 Türkiye Ön Raporu”, Aralık 2019, http://www.meb.gov.tr/meb_iys_ dosyalar/2019_12/03105347_PISA_2018_Turkiye_On_Raporu.pdf.
} 
deki öğretmen ve yöneticilerimizin mesleki gelişimleriyle ilgili de sorumluluk almalıdır. Bugün için bu sürecin ne kadar etkili yapıldığıyla ilgili KPSS sonuçlarına göre değerlendirmeler dışında kapsamlı bir rapora rastlanamamıştır. Eğitim fakülteleriyle ilgili problemleri birçoğumuz hissediyoruz ancak kapsamlı araştırma sonuçlarına rastlanmadığı için verileri net olarak ortaya koymak bugün için mümkün değildir.

Öğretmen özerkliği hizmet öncesi ve sonrası öğretmen eğitiminin niteliğinin artması süreci ile birlikte değerlendirilmelidir. Yeterlik, özerklik ve hesap verme eş zamanlı olarak ele alınmalıdır. Özerk olmayan, sürekli bir resmi yazı beklemek zorunda bırakılan bir öğretmenden kendisini sürekli yenilemesini, inisiyatif kullanmasını beklemek hayatın normal akışı ile yeterince uyumlu değildir. "Yönetim eğitilmeden, eğitim yönetilemez" yaklaşımının bir gereği olarak okul ve eğitim yöneticisi seçimleri ve eğitimleri ihmal edilebilecek bir alan değildir.

Yeni açılan eğitim fakülteleriyle birlikte (son birkaç yıl dışında) artan öğrenci sayıları, formasyon eğitimlerinde yaşanan sorunlar, orta öğretime öğretmen yetiştirmeyle ilgili belirsizlikler, öğretmen eğitiminin niteliğini olumsuz etkilemektedir. Özelikle orta öğretime öğretmen yetiştirmeyle ilgili belirsizlikler öğretmen yetiştirme geleneğine sahip, kadroları görece yeterli olan sınırlı sayıdaki eğitim fakülteleri bünyesindeki ortaöğretim öğretmenliği programlarının doluluk oranlarını olumsuz etkilemektedir.

Eğitim fakültelerinden beklenen rollerden biri de ulusal eğitim politikalarının belirlenmesine katkı vermeleridir. Bu rol gereğince özellikle öğretmen eğitimi konusunda belirli bir geleneğe sahip eğitim fakültelerinin hazırlayacakları raporlarla sürece katkı vermeleri gerekir. Bu raporlar, Millî Eğitim Bakanlığının bu konuda talebi olup olmadığına bakılmaksızın belirli dönemlerde kapsamlı olarak ya da güncel problemlere yönelik politika belgeleri şeklinde kamuoyuyla paylaşılmalıdır. Farklı disiplinlerden akademisyenlerin kurdukları sivil toplum örgütleri yoluyla ilgili alan öğretmen ve yöneticilerini de dâhil ederek belirli aralıklarla hazırlayıp kamuoyu ve ilgili kurumlarla paylaşacakları eğitim politikası belgeleriyle ulusal eğitim politikalarına katkıda bulunmaları gerekir.

Eğitim fakültelerinin yeni duruma göre rollerini ve yeteneklerini güncellemeleri onları çözümün bir parçası hâline getirecektir. Eğitim fakültelerindeki dinamik yapılanma ve ön alan tutum, kamuoyu desteğini daha çok kazanmalarına yol açacaktır. Bu destek bir taraftan ülke düzeyindeki eğitimin, diğer taraftan eğitim fakültelerinin niteliğinin gelişmesinde de katkıda bulunacaktır.

\section{Yükseköğretime Geçişte Nitelik Nicelik Çelişkisi}

Türkiye'de eğitimde reform denilince ilk önce K12 düzeyinde reform anlaşılsa da, Dünya'da eğitimde reform denilince ilk önce yükseköğretimde reform anlaşılır. Çünkü K12 düzeyinin bireye kazandırmak istediği bilgi ve beceriler yükseköğretim düzeyi kadar hızlı değişmez. Üstelik reform sözcüğü de kapsamlı ve çok boyutludur. Bilimsel bir hazırlık gerektirir. Uygulamada yapılan küçük oynamalar reform anlamına gelmez. Bazen eğitim politikaları üretenler en gerekli olan değişiklikler yerine en kolay gerçekleştirebilecekleri değişiklikleri yaparak kendi adlarına zaman 
kazanma yoluna gidebilirler. Bu nedenle bağımsız uzmanlar ve eğitim alanındaki sivil toplum örgütleri bu değişiklikleri analiz ederek kamuoyuna doğru bilgiyi vermeleri gerekir.

ÖSYM istatistiklerine göre 2020 yılı AYT ve YDT sınavına katılan öğrenci sayısı toplamı: 1 milyon 777 bin 882 , YÖK 2020 istatistiklerine göre ${ }^{10}$ lisans programlarına 4.538.926 öğrenci yerleşmiştir.

Puanlarımızı görece artırdığımız MEB 2018 PISA ön değerlendirme raporuna göre $^{11}$, öğrencilerimizden okuduğunu anlamada $\% 16,8$, matematikte $\% 15,7$ ve fen okuryazarlığında \%14,7'si 4. düzey ve üzerinde puan almışlardır. Özellikle 4. düzey ve üzerini dikkate aldım. Çünkü aşağıda okuduğunu anlama alanında verilen 3 . düzey yeterlik alanı dikkate alındığında bu yeterlik ve altındaki yeterlik düzeylerindeki öğrencilerin özellikle lisans programlarını ilgili disiplinin gerektirdiği yeterlikle tamamlayabilecekleri varsaymak doğru değildir. Bu durumu OECD Yetişkin Becerileri Araştırması ${ }^{12}$ doğrulamaktadır. Araştırma sonuçlarına göre yükseköğrenim düzeyinde eğitim görmüş yetişkinler ile lise üstü eğitim düzeyine sahip olmayanlar arasındaki sözel becerilerde yeterlilik farkı, OECD ortalaması 61 puan iken bu oran Türkiye'de 48 puandır, Bu durum Türkiye'de üniversiteye giriş yeterliklerinin yeniden gözden geçirilmesinin bir zorunluluk olduğunun göstergelerinden biri olarak kabul edilebilir.

PISA 3. Yeterlik Düzeyi: "Bu düzeydeki öğrenciler, açık şekilde sunulmadığ 1 durumlarda da metnin genel anlamını ifade edebilirler. Bilgileri derleyebilir, basit ve ileri düzeyde çıkarımlar yapabilirler. Çok uzun olmayan metinlerin ana düşüncesini belirlemek, ilişkileri anlamak, bir kelime veya ifadenin anlamını çıkarmak için metnin farklı bölümlerindeki bilgileri bir araya getirebilirler. Çeşitli kriterlere göre elde edilen bilgiler arasındaki ilişkileri anlayabilirler. Bu düzeydeki öğrenciler, bir veya birkaç metin üzerine derinlemesine düşünebilirler. Sunulan bilgilerden yola çıkarak farklı yazarların bakış açılarını kıyaslayabilirler."

Görüldüğü gibi bu düzeydeki öğrenciler genel düzeyde anlam çıkarma, çok uzun olmayan metinlerin ana düşüncesini belirleme konusunda yeterli durumdadırlar. Lisans eğitiminin bunun ötesinde yeterlik gerektirdiğini söyleyebiliriz.

2020 yılında AYT veya YDT sınavına katılan öğrencilerden \%39’u lisans programlarına yerleşmişlerdir. Bu durumda PISA'da 4. yeterlik alanı ve üzerinde en yüksek puanı aldığımız \%16,8 oranının üzerine çıktığımız görülmektedir. Bu konuda farklı değerlendirmeler yapılabilir. Ancak yükseköğretime geçiş sınavlarında bağıl değerlendirme yapıldığından öğrencinin aldığı puanla bir lisans programına yerleşse bile bu programın gerektirdiği temel giriş yeterliklerine sahip olup olmadığ 1 tartışmamız gereken konulardan biri olmalıdır. Bu tartışmalar, başka ölçütleri de

\footnotetext{
9 ÖSYM, “2020 Yükseköğretim Kurumları Sınavı (YKS): Sayısal Veriler”, 2020, https://dokuman.osym. gov.tr/pdfdokuman/2020/YKS/yks_sayisal_27072020.pdf.

${ }^{10}$ YÖK, "Öğrenim Düzeyine Göre Öğrenci Sayısı", 2020, https://istatistik.yok.gov.tr/.

11 "PISA 2108 Türkiye Ön Raporu”.

${ }^{12}$ OECD, “Skills Matter: Further Results from the Survey of Adults Skills 2015 (Turkey - Country Note)”, 2016, http://www.oecd.org/turkey/Skills-Matter-Turkey.pdf.
} 
dikkate alarak veriye dayalı olarak yapılmalı; yükseköğretim kontenjanları, öğrencilerin yeterlik düzeyleri ve özellikle lisans eğitimlerinin gerektirdiği temel yeterlikler de dikkate alınarak belirlenmelidir.

İsteyen herkesin yükseköğretimden yararlanması temel ilke olarak kabul edilebilir. Ancak bu istekle birlikte girişte temel yeterliklerin aranması yükseköğretimin kendi amaçlarına ulaşabilmesi için kaçınılmaz bir durumdur. Eğer yükseköğretimde kontenjanları artırmak istiyorsak okul öncesinden başlayarak öğrencilerin yeterlik düzeylerini geliştirmek zorundayız. Aksi durumda tek başına öğretim üyesi niteliğini artırmak ya da öğretim materyallerini zenginleştirmek, istediğimiz sonuçları almaya yetmeyecektir.

Özellikle yükseköğretim alanını etkileyen değişimlerden biri de, kitlesel uzaktan eğitimin (Massive Open Online Courses) özellikle yükseköğretim kademesinde milyonlarca öğrencinin yararlandığı ortamlar hâline gelmesidir. Başta yükseköğretim olmak üzere eğitim sistemimizin bunun dişında kalması düşünülemez. $\mathrm{Bu}$ nedenle üniversitelerimiz, hazırlayacakları platformlarda hem kendi öğrencilerine, mezunlarına yönelik hem de talep eden herkesi dikkate alan dinamik programlarla bu sürecin bir parçası olmak durumundadırlar.

\section{Sonuç}

Bugünün dünyasında eğitim üzerine yalnızca ülkelerin eğitim bakanlıkları araştırma yapmıyorlar. Ulusal veya uluslararası ölçekte çok sayıda resmi ya da sivil toplum kuruluşu kendi kuruluş amaçları çerçevesinde eğitim sistemlerine yönelik araştırmalar yaparak ve politika önerilerinde bulunmaktadırlar. Özellikle OECD, Dünya Bankası gibi ekonomi öncelikli kuruluşlar neredeyse en az eğitim bakanlıkları kadar eğitimle ilgili görünmektedirler. Eğitim sistemlerinin çıktılarının ekonominin girdilerini oluşturduğu düşünüldügünde bu ilgi anlaşılabilir durumdadır. Ayrıca Avrupa Eğitim Bilgi Ağı (EURYDICE) gibi ulusal eğitim politika yapıcılarına destek amacıyla kurulmuş olan uluslararası kuruluşlar eğitim sistemlerinin amaçları ve süreçleri üzerine büyük etkiler oluşturmaktadırlar.

Eğitim sisteminin bir parçası olan politika yapıcılar, akademisyenler ve öğretmenler hangi ülkede yaşadıklarından bağımsız olarak uluslararası eğitim alan yazınından farkına vararak ya da varmayarak büyük oranda etkilenmektedirler. Bu nedenle eğitime hem sistemin içinden hem de dışından bakabilmenin yollarını bulmamız ve nitelikli araştırmalar yaparak politika önerilerinde bulunabilmemiz gerekir. Bugün için eğitim alan yazını üzerine daha çok etki edebilen kurumlar veya kişiler ulusal eğitim sistemlerini yönlendirebilmektedirler.

Makale, yukarıda sayılan kurum ve kuruluşların araştırma ve politika önerileri başta olmak üzere kaynaklarda verilen araştırmaların alan yazın taramasına bağlı olarak yapılan bir değerlendirmesini içermektedir. Makalenin amacı bir sonuca varmak değildir. Sistemi yeniden düşünmemiz için bir küçük başlangıç yapabilirsek amaç gerçekleşmiş demektir. Okurda makalenin başına, ortasına veya sonuna yeni fikirler eklemek ya da bazı fikirleri çıkarmak isteği oluşturmuşsa yapılan bu küçük çabaya değmiş demektir. Makaleden beklenti, eğitim politikaları alanında 
açılan bu küçük çukurun alanda yazılan diğer makalelerle suyunu içebileceğimiz kuyuya dönüşmesidir.

\section{Kaynakça}

Hansen, Michael E. "Higher Education Needs Dusting off for the 21st Century". World Economic Forum (WEF) İnternet Sitesi. 27 Mart, 2018. https:// www.weforum.org/agenda/2018/03/make-higher-education-skills-relevantfor-students/.

Millî Eğitim Bakanlığı. "Millî Eğitim İstatistikleri: Örgün Eğitim (2019/20)". https://sgb.meb.gov.tr/meb_iys_dosyalar/2020_09/04144812_meb_istatistikle ri_orgun_egitim_2019_2020.pdf.

Millı̂ Eğitim Bakanlığı. "PISA 2108 Türkiye Ön Raporu”. Aralık 2019, http:// www.meb.gov.tr/meb_iys_dosyalar/2019_12/03105347_PISA_2018_Turkiye _On_Raporu.pdf.

OECD. "OECD Future of Education and Skills 2030 Concept Note". 2019. https://www.oecd.org/education/2030-project/teaching-and-learning/learning/ skills/Skills_for_2030_concept_note.pdf.

OECD. “PISA 2018 Results”. 2019. https://www.oecd.org/pisa/publications/pisa2018-results.htm.

OECD. "Skills Matter: Further Results from the Survey of Adults Skills 2015 (Turkey - Country Note)”. 2016. http://www.oecd.org/turkey/Skills-MatterTurkey.pdf.

OECD. "The Future of Education and Skills Education 2030". (Position Paper). 2018. http://www.oecd.org/education/2030-project/about/documents/E2030 Position Paper (05.04.2018).pdf.

ÖSYM. "2020 Yükseköğretim Kurumları Sınavı (YKS): Sayısal Veriler”. 2020. https://dokuman.osym.gov.tr/pdfdokuman/2020/YKS/yks_sayisal_27072020. pdf.

UNDP. “2019 Human Development Index Ranking”. 2019. http://hdr.undp.org/ en/content/2019-human-development-index-ranking.

Yavuz, Mustafa. Başımıza İcat Çıkaran Çocuklar ve Gençler. Ankara: Pegem Akademi Yayınları, 2020.

YÖK, “Öğrenim Düzeyine Göre Öğrenci Sayısı”. 2020. https://istatistik.yok.gov.tr/. 


\title{
Conceptual Construction of Fair, Inclusive and Holistic Education Policies Based on Human and Meaning
}

\author{
MUSTAFA YAVUZ
}

Abstract: Education systems are living organisms. They breathe. Sometimes they can go into crisis. Crises can turn into new opportunities only if the people, meanings and possibilities that make up the system can work effectively. Education systems must first be built in the minds of individuals who make up the state. Since education systems constantly reproduce a society, the state, it is not possible to understand a society or a state without understanding it. The article does not aim to form a final opinion on the education system, but to rethink it first.

Keywords: Education, Purpose, Individual, Society, State 